\title{
INFLUENCE OF FACET TROPISM ON THE LOCATION OF LUMBAR DISC HERNIATION
}

\author{
A INFLUÊNCIA DO TROPISMO FACETÁRIO SOBRE A LOCALIZAÇÃO DA HÉRNIA \\ DISCAL LOMBAR
}

\section{INFLUENCIA DEL TROPISMO FACETARIO EN LA UBICACIÓN DE LA HERNIA DE DISCO LUMBAR}

\author{
Rodrigo Arnold Tisot ${ }^{1-2}$, Juliano da Silveira Vieira², Diego da Silva Collares², Leonardo Domingues Stumm², Mariano Feraboli Fontana², Augusto Pasinl ${ }^{2}$ \\ Eduardo Coronel ${ }^{2}$, Eduardo Scharnovski ${ }^{2}$, Maiara Agostinl ${ }^{2}$, Mateus Borin², Victor Kasper ${ }^{2}$, Victor Sánchez ${ }^{2}$, Walter Iserhard ${ }^{2}$ \\ 1. Medical School of the Universidade de Passo Fundo (UPF), Passo Fundo, RS, Brazil. \\ 2. Hospital Ortopédico de Passo Fundo, Passo Fundo, RS, Brazil.
}

\begin{abstract}
Objective: To correlate facet tropism with the side and location of the intervertebral disc in which the lumbar disc herniation occurred. Methods: A retrospective descriptive study that evaluated Magnetic Resonance Imaging of 255 patients with lumbar disc herniation undergoing surgical treatment with the Spine Group of the Hospital Ortopédico de Passo Fundo between 2002 and 2014. The total patient number was stratified according to the side affected by the herniated disc (right or left), location of the hernia in the intervertebral disc (central, centrolateral, foraminal and extraforaminal) and demographic data, such as age, gender etc. The degree of facet joint tropism was measured by the Karakan method and classified as mild (difference less than $7^{\circ}$ ); moderate (between $7^{\circ}$ and $15^{\circ}$ ) and severe $($ difference greater than $\left.15^{\circ}\right)$. Results: A statistical significant relationship $(p=0.023)$ was observed between the facet joint tropism and the side where the lumbar disc herniation occurred. No correlation was found between facet joint tropism and location of the herniation on the intervertebral disc. Conclusions: The degree of facet tropism presents a statistical significant correlation with the side of the intervertebral disc in which the lumbar disc herniation will develop. Level of Evidence: II. Type of study: Retrospective study.
\end{abstract}

Keywords: Tropism; Orientation; Herniated disc; Facet degeneration.

\section{RESUMO}

Objetivo: Correlacionar o tropismo facetário com o lado e local do disco intervertebral no qual ocorreu a hérnia discal lombar. Métodos: Estudo retrospectivo descritivo, no qual foram avaliados exames de Ressonância Nuclear Magnética de 255 pacientes com hérnia discal lombar submetidos a tratamento cirúrgico pelo Grupo de Coluna do Hospital Ortopédico de Passo Fundo, entre os anos de 2002 e 2014. Estratificou-se o total de pacientes pelo lado acometido pela hérnia discal (direito ou esquerdo), localização da hérnia no disco intervertebral (central, centro-lateral, foraminal e extra-foraminal) e por dados epidemiológicos, como idade, sexo etc. O grau de tropismo facetário foi mensurado pelo método de Karakan e classificado entre leve (diferença menor que $7^{\circ}$ ), moderado (entre $7^{\circ}$ e $15^{\circ}$ ) e grave (diferença maior que $\left.15^{\circ}\right)$.Resultados: Foi verificada relação estatisticamente significativa $(p=0,023)$ entre o tropismo facetário e o lado em que ocorreu a hérnia discal lombar. Não foi encontrada correlação entre tropismo facetário e localização da hérnia discal no disco intervertebral. Conclusão: O grau de tropismo facetário apresenta correlação estatisticamente significativa com o lado do disco intervertebral no qual irá se desenvolver a hérnia discal. Nível de Evidência: II. Tipo de Estudo: Estudo retrospectivo.

Descritores: Tropismo; Orientação; Hérnia discal; Degeneração facetária.

\section{RESUMEN}

Objetivo: Correlacionar el tropismo facetario con el lado y local del disco intervertebral en el cual ocurrió la hernia del disco lumbar. Métodos: Estudio retrospectivo descriptivo, en el fueron evaluados exámenes de resonancia magnética nuclear de 255 pacientes con hernia discal lumbar sometidos a tratamiento quirúrgico por el Grupo de Columna Vertebral del Hospital Ortopédico de Passo Fundo, entre los años 2002 y 2014. El número total de pacientes fue estratificado de acuerdo con el lado acometido por la hernia discal (izquierda o derecha), localización de la hernia en el disco intervertebral (central, centro-lateral, foraminal o extra-foraminal) y datos epidemiológicos como edad, sexo etc. El grado de tropismo facetario fue medido por el método de Karakan y clasificado como leve (diferencia menor que $7^{\circ}$ ), moderado (entre $7^{\circ}$ y $1^{\circ}$ ) y grave (diferencia mayor que $15^{\circ}$ ). Resultados: Se verificó una relación estadísticamente significativa $(p=0,023$ ) entre el tropismo facetario y el lado en que ocurrió la hernia discal lumbar. No se encontró correlación entre el tropismo facetario y la localización de la hernia en el disco intervertebral. Conclusiones: El grado de tropismo facetario presenta correlación estadísticamente significativa con el lado del disco intervertebral en el cual se desarrollará la hernia discal lumbar. Nivel de evidencia: II. Tipo de Estudio: Estudio retrospectivo.

Descriptores: Tropismo; Orientación; Hernia discal; Degeneración facetaria.

Study conducted by the Spine Group of the Hospital Ortopédico de Passo Fundo (HO) and the Medical School of the UPF - Passo Fundo, Passo Fundo, RS, Brazil. Correspondence: Av. Sete de Setembro, 817. Passo Fundo, RS, Brazil. 99010-121. rtisot@ hotmail.com 


\section{INTRODUCTION}

Herniation of the lumbar disc is a common musculoskeletal pathology, many times causing intense lumbosciatalgia. The term disc herniation is used to describe a process in which the fibrous annulus ruptures, with the subsequent displacement of the central disc mass outside the intervertebral spaces, usually on the dorsal or dorsolateral side of the disc. ${ }^{1}$ Problems stemming from this disorder are the most frequent causes of absences from work due to disability and constitute a global public health issue. ${ }^{2}$ It can occur in any age group, but is predominant in the 40 to 50 years of age group. It is estimated that if affects 2 to $3 \%$ of the population, or approximately $5 \%$ of men and $2.5 \%$ of women. ${ }^{3}$

The literature shows that the etiopathogenesis is multifactorial and correlated with habits of day to day life, such as lifting weight, smoking, obesity, as well as the natural aging process, genetic predisposition, and anatomical changes. ${ }^{4}$ Recent studies have indicated that genetic influence plays a primary role in the physiopathology of disc degeneration and can increase the risk of developing the disease or even act as a regulating factor, modulating the severity and magnitude of the pathology, as well as the response to treatment. ${ }^{5}$

The angle of the facet joint corresponds to its orientation in the transverse (axial) plane. Facet tropism is the asymmetry between the left and right facet angles, when one has a more sagittal orientation as compared to the contralateral angle. ${ }^{6}$ Noren et al. reported that facet tropism is associated with the development of herniation and disc degeneration at all lumbar levels. ${ }^{7}$ Spinopelvic balance is the interaction of the vertebral morphology with the pelvis and it acts directly on the mechanical function of the discs, ligaments, and muscle resistance. These mechanisms permit the individual to be able to stay in a standing position and to mobilize with the least energy expenditure. The imbalance of these mechanisms can influence the development of disc herniation. ${ }^{8,9}$

Studies already conducted ${ }^{10,11}$ about the association between degenerative disc disease, spondylolisthesis, facet tropism, and lumbar disc herniation, were only focused on ascertaining the cause and effect relationship between them. The objective of this study is to evaluate whether a correlation exists between facet tropism and the side and location of the vertebral disc where lumbar disc herniation occurred.

\section{METHODS}

A cross-sectional, descriptive analytic study was conducted to evaluate the Magnetic Resonance Imaging (MRI) exams of 255 patients with lumbar disc herniation who underwent surgical treatment at the Spine Surgery Service of the Hospital Ortopédico de Passo Fundo (RS) during the period from 2002 to 2014

The authors signed the Informed Consent Form (ICF) to use the data, committing to do so anonymously. The research project was approved by the Institutional Review Board of the Universidade de Passo Fundo (IRB/UPF), after having been forwarded to the Plataforma Brasil, as protocol number 2.018.312.

As inclusion criteria, patients with a diagnosis of lumbar disc herniation at only one level who underwent surgery were selected. All cases were required to have a Magnetic Resonance Imaging exam (MRI) of the lumbar spine with T1- and T2-weighted axial cuts.

Patients with a diagnosis of lumbar disc herniation at more than one level, patients with spondylolisthesis, and those with deviation of the sagittal axis of more than $10^{\circ}$ were excluded.

The anatomic location of the lumbar disc herniation in the axial plane, in relation to the location of the vertebral canal in which it occurred, was classified as central, central lateral, foraminal, and extraforaminal, according to the classification proposed by Wiltse et al. ${ }^{12}$ For this definition, axial cuts of the T1- and T2-weighted MRI exam were used.

The facet angle was measured using the method of Karacan et al. ${ }^{13}$ For this purpose, the T1-weighted MRI axial cuts were used. In this method, a line between the two margins of each of the upper facet joints is drawn through the center of the spinous process for each hemi-side of the image used. The tropism, then, is obtained by calculating the difference between the right facet angle and the left facet angle (Figure 1).
The severity of the tropism was classified according to the methodology described by Vanharata et al., ${ }^{14}$ who divided facet tropism into mild (differences less than $7^{\circ}$ ), moderate (differences between $7^{\circ}$ and $15^{\circ}$ ), and severe (differences greater than $15^{\circ}$ ).

The chi-square test was used for analysis and calculation of results via the SPSS statistics program, with a significance level of 0.05 $(\alpha=5 \%)$. Descriptive levels (p) less than this value were considered significant and represented as $p<0.05$.

\section{RESULTS}

The results were obtained according to $(A)$ demographic data, (B) the evaluation of facet tropism, (C) the correlation between facet tropism and the side where the disc herniation occurred, and (D) the correlation between facet tropism and the location in the herniated disc.

\section{A. Demographic data}

One hundred and twenty-six patients were male (49.4\%) and 129 were female (50.6\%). The patients ranged in age from 19 to 77 years with an average of 48 years of age.

As regards the interval where the disc herniation occurred, the predominance of involvement was in the L5-S1 interval, in 120 patients (47.1\%), and in L4-L5, in 109 patients (42.7\%). (Table 1).

Regarding the side where the disc herniation occurred, $135 \mathrm{pa}$ tients were affected on the left (52.9\%) and 120 on the right (47.1\%).

When evaluating the intervertebral disc location where the lumbar disc herniation occurred, we found that in 204 patients (80\%) it was central lateral, in 21 patients (8.2\%) foraminal, in 19 patients $(7.5 \%)$ central, and in 11 patients (4.3\%) extra-foraminal. (Table 2)

\section{B. Evaluation of facet tropism}

In our evaluation of facet tropism, we found a slight tendency towards greater asymmetry on the left, in 126 patients (50.4\%), than on the right, in 124 patients (49.6\%). Only five patients did not present facet asymmetry. (Table 3 )

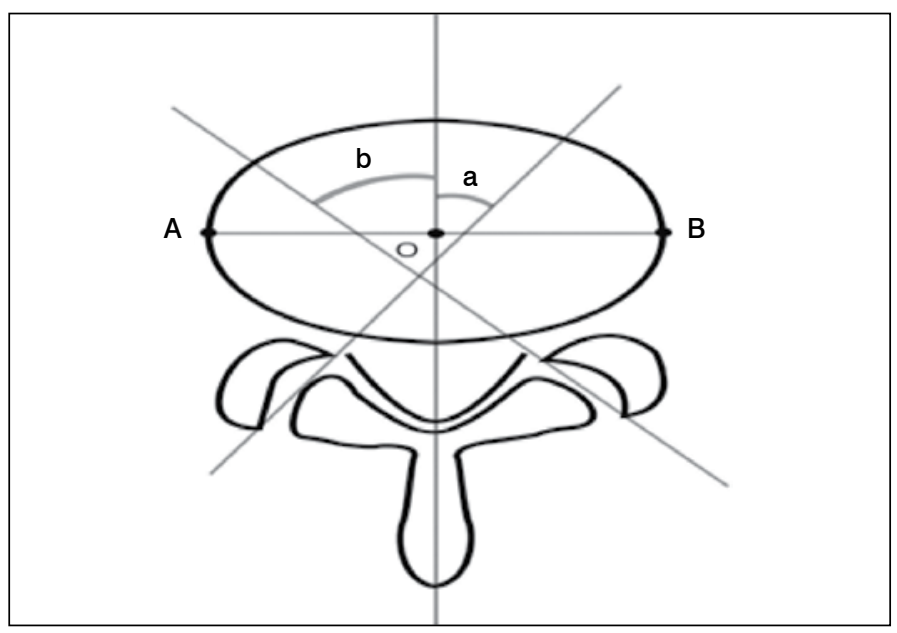

Figure 1. Measurement of facet tropism.

Table 1. Lumbar disc intervals where disc herniation occurred.

\begin{tabular}{c|c|c}
\hline & $\mathbf{N}$ & $\%$ \\
\hline L2-L3 & 4 & 1.6 \\
\hline L3-L4 & 12 & 4.7 \\
\hline L4-L5 & 109 & 42.7 \\
\hline L4-VT & 5 & 2.0 \\
\hline L5-S1 & 120 & 47.1 \\
\hline L5-VT & 5 & 2.0 \\
\hline total & 255 & $100 \%$
\end{tabular}




\section{Correlation between facet tropism and the side where the disc herniation occurred.}

A statistically significant correlation $(p=0.023)$ was observed between facet tropism and the side where the lumbar disc herniation occurred (Table 4). However, we confirmed that the side of the facet asymmetry with the greater angulation (more coronal orientation) was also the side where most of the herniations occurred.

\section{Correlation between facet tropism and the location of the disc herniation}

There was no statistically significant correlation $(p=0.902)$ between the degree of facet asymmetry and the location in the intervertebral disc where the lumbar disc herniation occurred. (Table 5)

Table 2. Intervertebral disc locations where disc herniation occurred.

\begin{tabular}{c|c|c}
\hline & N & $\%$ \\
\hline Central & 19 & 7.5 \\
\hline Central lateral & 204 & 80.0 \\
\hline Foraminal & 21 & 8.2 \\
\hline Extra-foraminal & 11 & 4.3 \\
\hline Total & 255 & $100 \%$ \\
\hline
\end{tabular}

Table 3. Analysis of facet tropism.

\begin{tabular}{c|c|c}
\hline & Frequency & Percentage \\
\hline Right tropism & 124 & 48.6 \\
\hline Left tropism & 126 & 49.4 \\
\hline Symmetrical facets & 5 & 1.9 \\
\hline Total & 255 & $100 \%$ \\
\hline
\end{tabular}

Table 4. Facet tropism and the side where the disc herniation occurred.

\begin{tabular}{c|c|c|c}
\hline & \multicolumn{2}{|c|}{ Side of the disc herniation } & Total \\
\hline & Right & Left & \\
\hline Right tropism & 67 & 57 & 124 \\
\hline & $54 \%$ & $46 \%$ & $100 \%$ \\
\hline Left tropism & 49 & 77 & 126 \\
\hline $\begin{array}{c}\text { Absence of facet } \\
\text { asymmetry }\end{array}$ & $38.9 \%$ & $61.1 \%$ & $100 \%$ \\
\hline & 4 & 1 & 5 \\
\hline
\end{tabular}

Table 5. Correlation between facet tropism and the location of the lumbar disc herniation.

\begin{tabular}{c|c|c|c|c}
\hline & Mild tropism & $\begin{array}{c}\text { Moderate } \\
\text { tropism }\end{array}$ & $\begin{array}{c}\text { Severe } \\
\text { tropism }\end{array}$ & Total \\
\hline Central & 12 & 6 & 1 & 19 \\
\hline Central lateral & 125 & 68 & 11 & 204 \\
\hline Foraminal & 13 & 7 & 1 & 21 \\
\hline Extra foraminal & 6 & 3 & 2 & 11 \\
\hline Total & 156 & 84 & 15 & 255 \\
\hline
\end{tabular}

\section{DISCUSSION}

Disc herniation is a common pathology that causes serious disability in those affected and is a global health problem. ${ }^{15}$ The degenerative disc process has been associated with an interaction between environmental effects, local aggressions and traumas, lifestyle habits, bearing of weight, tobacco use, atherosclerosis, plus possible anatomic factors such as spinopelvic balance, tropism, and facet orientation, as well as changes that come with the aging process. Studies have shown that these effects act modestly on disc degeneration, reinforcing the preponderance of genetic factors in this process. ${ }^{16-18}$ However, there has been a relatively recent increase in the number of studies trying to determine whether orientation and facet tropism have a statistically significant influence on disc degeneration, spondylolisthesis, and disc herniation. Today, these relationships, previously supposed by researchers, are better understood due to technological advances in imaging exams (such as magnetic resonance and high resolution computed tomography) that allow us to obtain a more detailed study of the anatomy of the facet joint (of the joint processes), as well as a more precise evaluation of the changes in geometric orientation.

As regards the relationship between the anatomic variations of the facet joint and instability of the spine, studies have shown that the coronal orientation of the facet joints tends to be less resistant to shear forces, turning on the side where the facet is more coronally oriented, which may lead to instability of the isthmic type. This asymmetry increases the rotational force of one side of the spine, causing spondylolisthesis on the side where the facet joint is more coronally oriented and, consequently, increasing the tension on the intervertebral disc. ${ }^{19}$ Moreover, authors such as Fujiwara, ${ }^{20}$ Boden, ${ }^{21}$ and Samartzis et al. ${ }^{22}$ reported a correlation between an increase in the incidence of degenerative spondylolisthesis at level L4-L5 and facet joints with a sagittal orientation. However, other studies ${ }^{23-24}$ observed variations in the results when they studied different ethnic groups and when they used different definitions of the grades of facet tropism in their analyses.

As for articles that relate angulation and facet tropism to the degenerative disc process, Noren et al. ${ }^{7}$ reported that facet tropism may be associated with the development of herniation and disc degeneration at all lumbar levels. However, Cassidy et al. ${ }^{25}$ and Vanharanta et al. ${ }^{14}$ did not find any relationship between facet tropism and lumbar disc degeneration. Costa et al. ${ }^{26}$ in their article assessing the relationship between facet tropism and degenerative lumbar disc disease, concluded that there is an increase in facet tropism with aging as a result of the progressive degenerative process.

In our study, we sought to specifically evaluate the correlation of facet tropism with the side and the location in the vertebral disc where the lumbar disc herniation occurred, considering that these relationships had been little explored in the academic environment to date. During the literature review, we found no other similar article in the national sphere that reported having conducted this specific analysis. The high number of patients included in the study and the epidemiological characteristics encountered, similar to the normal distribution of lumbar disc herniation involvement in our population, reinforced its validity.

The results obtained in this study showed that facet tropism undoubtedly plays a role in the distribution of stress on the intervertebral disc, affecting it unevenly and, thus, causing a higher incidence of disc herniation on the side corresponding to that of the tropism $(p=0.023)$, in a manner analogous to that described for the occurrence of lesion of the pars interarticularis. In our opinion, a more coronal orientation of one of the facets (side of the tropism) tends to be less resistant to shear forces. For this reason, the intervertebral disc tends to suffer greater rotational load (twist) on the side of the more coronally-oriented facet joint, requiring greater effort and causing progressive damage to the fibers of the fibrous annulus of this region. If we take into account the delicate balance of the forces that bring stability to the spine, a complex structure made up of bones, ligaments, muscles and discs that provides our body with both rigid support and relatively wide-ranging mobility, we can understand how even a subtle asymmetry in one of its structures (such as facet tropism) can lead to significant changes in the development and characteristics of the natural degenerative and pathologic process.

Using the classification by zones suggested by Wiltse et al. ${ }^{12}$ for our evaluation, we found no statistically significant correlation $(p=0.902)$ between facet tropism and the location in the intervertebral disc where the disc herniation occurred. We believed that the greater the facet asymmetry (facet joint with a more coronal orientation), the greater the tendency towards more lateral disc herniation (foraminal or extraforaminal). However, this hypothesis was not confirmed, possibly because there are other biomechanical characteristics that interfere in the exact location in the intervertebral disc in question where overload and progressive damage to the fibers of the fibrous annulus occur. 
There is no doubt that other factors may interfere in the genesis of disc herniation. Thus, the conflicting results sometimes found in the several studies conducted corroborate the hypothesis that multiple factors play a significant role in its formation. A more in-depth analysis of all these factors would perhaps help to better define those which are most important in the genesis of the pathology, and thus enable better orientation for both prevention and postponement in patients who are more predisposed to herniation.

\section{CONCLUSIONS}

A statistically significant correlation was observed between facet tropism and the side of the intervertebral disc where the lumbar disc herniation occurred. However, there was no statistically significant correlation between the degree of facet asymmetry and the location in the intervertebral disc where the lumbar disc herniation occurred.

According to the results of this study, we believe that a more coronally orientation of one of the facet joints (the side of the tropism) tends to have less resistance to shear forces. Thus, the intervertebral disc tends to suffer greater rotational load (twist) to the side of the most coronally-oriented facet joint, requiring greater effort and causing progressive damage to the fibers of the fibrous annulus of this region.

All authors declare no potential conflict of interest related to this article.

CONTRIBUTION OF THE AUTHORS: Each author made significant individual contributions to this manuscript. RAT (0000-0001-5970-3227)* was the creator of and advisor for each of the stages of the research, as well as the promotor of the study patients. JSV $(0000-0002-4796-6393)^{\star}$ and DSC(0000$0002-3994-9286)^{\star}$ contributed to the editing of the article. LDS(0000-0002-7212-4112)* and MFF(0000-0002-9958-3765)* collected the data from the medical records and participated in the preparation of the results and the development of the text. AP (0000-0002-7194-141X)* EC (0000-0002-04785816), ES (0000-0002-7151-1778)*, MA(0000-0003-3556-2698)*, MB(0000-0001-9280-6674) ${ }^{\star}, \mathrm{VK}(0000-0001-6911-133 X)^{\star}$, VS(0000-0003-2932-6429)*, and $\mathrm{WI}(0000-0002-7362-1364)$ conducted the literature review and participated actively in the preparation of the statistics and the text. ${ }^{*} \mathrm{ORCID}(\mathrm{Open}$ Researcher and Contributor ID).

\section{REFERENCES}

1. Mixter WJ, Barr JS. Rupture of intervertebral disc with involvement of the spinal canal. N Engl J Med. 1934;211:210-5.

2. Atlas SJ, Chang Y, Kammann E, Keller RB, Deyo RA, Singer DE. Long term disability and return to work among patients who have a herniated lumbar disc: the effect of disability compensation. J Bone Joint Surg Am. 2000;82(1):4-15.

3. Vialle LR, Vialle EN. Hérnia Discal Lombar. Rev Bras Ortop. 2010;45(1):17-22.

4. Jacobsen S, Sonne-Holm S, Rovsing H, Monrad H, Gebuhr P. Degenerative lumbar spondylolisthesis: an epidemiological perspective. The Copenhagen Osteoarthritis Study. Spine (Phila Pa 1976). 2007;32(1):120-5.

5. Henrotin YE, Cedraschi C, Duplan B, Bazin T, Duquesnoy B. Information and low back pain management: a systematic review. Spine (Phila Pa 1976). 2006;31(11):E326-34.

6. Silva CIS, D'Ippolito G, Rocha AJ. Doença degenerativa da coluna vertebral. In: Fernades JL. Coluna vertebral. Rio de Janeiro: Elsevier; 2011. p.153-98.

7. Noren R, Trafimow J, Andersson GB, Huckman MS. The role of facet joint tropism and facet angle in disc degeneration. Spine (Phila Pa 1976). 1991;16(5):530-2.

8. Barrey C, Roussouly P, Perrin G, Le Huec JC. Sagittal balance disorders in severe degenerative spine. Can we identify the compensatory mechanisms? Eur Spine J. 2011;20(Supp|5):626-33.

9. Barrey C, Jund J, Noseda O, Roussouly P. Sagittal balance of the pelvis-spine complex and lumbar degenerative diseases. A comparative study about 85 cases. Eur Spine J. 2007:16(9):1459-67.

10. Lee DY, Ahn Y, Lee SH. The influence of facet tropism on herniation of the lumbar disc in adolescents and adults. J Bone Joint Surg Br. 2006;88(4):520-3.

11. Jentzch T, Geiger J, Zimmermann SM, Slankamenac K, Nguyen-KimTD, Werner CM. Lumbar facet joint arthritis is associated with more coronal orientation of the facet joints at the upper lumbar spine. Radiol Res Pract. 2013;2013:693971.

12. Wiltse $L L$, Berger PE, McCulloch JA. A system for reporting the size and location of lesions in the spine. Spine (Phila Pa 1976). 1997:22(13):1534-7.

13. Karacan I, Aydin T, Sahin Z, Cidem M, Koyuncu H, Aktas I, et al. Facet angles in lumbar disc herniation: their relationto anthropometric features. Spine. 2004;29(10):1132-6.

14. Vanharanta H, FloydT, Ohnmeiss DD, Hochschuler SH, Guyer RD. The relationship of facet tropism to degenerative disc disease. Spine (Phila Pa 1976). 1993;18(8):1000-5.

15. Long DM, Ben Debba M, Torgerson WS, Boyd RJ, Dawson EG, Hardy RW, et al. Persis- tent back pain and sciatica in the United States: patient characteristics. J Spinal Disord. 1996;9(1):40-58

16. Videman T, Leppavuori J, Kaprio J, Battié M, Koskenvuo M. Intragenic polymorphisms of the vitamin D receptor gene associated with intervertebral disc degeneration. Spine (Phila Pa 1976). 1998;23(23):2477-85

17. Battié MC, Videman T, Parent E. Lumbar disc degeneration: epidemiology and genetic influences. Spine (Phila Pa 1976). 2004; 29(23):2679-90.

18. Battie MC, Videman T, Gibbons LE, Fisher LD, Manninen H, Gill K. Volvo Award in Clinical Sciences. Determinants of lumbar disc degeneration. A study relating lifetime exposures and magnetic resonance findings in identical twins. Spine (Phila Pa 1976). 1995:20(24):2601-12

19. Rankine JJ, Dickson RA. Unilateral spondylolysis and the presence of facet joint tropism. Spine (Phila Pa 1976). 2010;35(21):E1111-4.

20. Fujiwara A, Tamai $\mathrm{K}$, An HS, Kurihashi T, Lim TH, Yoshida H. The relationship between disc degeneration, facet joint osteoarthritis, and stability of the degenerative lumbar spine. J Spinal Disor. 2000; 13(5):444-50

21. Boden SD, Riew KD, Yamaguchi K, Branch TP, Schellinger D, Wiesel SW et al. Orientation of the lumbar facet joints: association with degenerative disc disease. J Bone Joint Surg Am. 1996;78(3):403-11.

22. Samartzis $D$, Cheung JP, Rajasekaran $S$, KawaguchiY, Acharya $S$ et al Critical Values of Facet Joint Angulation andTropism in the Development of Lumbar Degenerative Spondylolisthesis: An International, Large-Scale Multicenter Study by the AOSpine Asia Pacific Research Collaboration Consortium. Global Spine J. 2016;6(5)414-21.

23. Berlemann U, Jeszenszky DJ, Bühler DW, Harms J. Facet joint remodeling in degenerative spondylolisthesis: an investigation of joint orientation and tropism. Eur Spine $\mathrm{J}$. 1998;7(5):376-80

24. Dai LY. Orientation and tropism of lumbar facet joints in degenerative spondylolisthesis. Int Orthop. $2001 ; 25(1): 40-2$.

25. Cassidy JD, Loback D, Yong-Hing K, Tchang S. Lumbar facet joint assymmetry. Intervertebral disc herniation. Spine (Phila Pa 1976).1992;17(5):570-4.

26. Costa $A B$, Mattar T, Appolonio PR. Associação entre tropismo facetário e doença degenerativa de disco lombar. Coluna/Columna. 2013;12(2):133-7. 